University of Nebraska - Lincoln

DigitalCommons@University of Nebraska - Lincoln

6-2003

\title{
JECP/ED - A computer program for simulation of selected-area and precession electron diffraction patterns
}

Xingzhong Li

University of Nebraska - Lincoln, xli2@unl.edu

Follow this and additional works at: https://digitalcommons.unl.edu/cmrafacpub

Part of the Nanoscience and Nanotechnology Commons

$\mathrm{Li}$, Xingzhong, "JECP/ED - A computer program for simulation of selected-area and precession electron diffraction patterns" (2003). Faculty Publications from Nebraska Center for Materials and Nanoscience. 104.

https://digitalcommons.unl.edu/cmrafacpub/104

This Article is brought to you for free and open access by the Materials and Nanoscience, Nebraska Center for (NCMN) at DigitalCommons@University of Nebraska - Lincoln. It has been accepted for inclusion in Faculty Publications from Nebraska Center for Materials and Nanoscience by an authorized administrator of DigitalCommons@University of Nebraska - Lincoln. 
Published in Journal of Applied Crystallography 36:3 (June 2003), pp. 956; doi: 10.1107/S0021889803007933

Copyright $\odot 2003$ International Union of Crystallography; published by Wiley-Blackwell. Used by permission.

Submitted January 23, 2003; accepted March 31, 2003.

\title{
$J E C P / E D$ - A computer program for simulation of selected-area and precession electron diffraction patterns
}

\author{
X. Z. Li \\ Center for Materials Research and Analysis, \\ University of Nebraska-Lincoln, Lincoln, NE 68588, USA; email xli2@unl.edu
}

Keywords: electron diffraction, precession technique, computer simulation

\section{The crystallographic problem}

Crystal structure determination by electron crystallography has been very successful in many fields, ranging from organic to inorganic materials. Collection of electron diffraction data is still a crucial step in electron crystallography. The curvature of the Ewald sphere limits the data available in each electron diffraction pattern. The dynamical multi-scattering effect of electron diffraction increases the complexity of the structure determination procedure.

A precession method (Vincent \& Midgley, 1994) has been used to solve the crystal structure of $\mathrm{Al}_{m} \mathrm{Fe}$ by Gjonnes and coworker (Berg et al., 1998; Gjonnes et al., 1998). The advantages of precession electron diffraction are (i) the effective reduction of the dynamical multi-scattering effects, (ii) an increase in the amount of electron diffraction data due to the precession of the electron beam, (iii) the ability to obtain integrated intensity of each electron diffraction spot.

In the present work, an electron diffraction simulation program, $J E C P / E D$, is reported. The program can be used as a teaching aid for students as well as a tool for scientists working on electron diffraction experiments.

\section{Method of solution}

As the precession technique is implemented based on the selected-area electron diffraction method, the program is designed for fully functional selected-area electron diffraction simulation and is extended to include precession diffraction simulation.

In the program, diffraction patterns with geometrical factors and kinematical intensities are calculated in two separate steps. There are options to show the index, the intensity, the base vector, the Laue center and the ZOLZ or ZOLZ + FOLZ. The parameters of camera length, rotational angle and tilt angle of the incident electron beam are needed in the calculation.

There are two options in the simulation of precession electron diffraction: animation of the process and the final integrated diffraction pattern. Three parameters can be set for the simulation: steps per cycle, time per step (for optimal visual effects in the simulation) and the beam tilt angle.
Independent atoms in the asymmetric unit and spacegroup number are needed in the input file; all atom positions are generated by the program using the space-group symmetry operations. The structure factors for the electron diffraction intensity are calculated using the analytical approximation for obtaining the atomic scattering factors.

\section{Program specification}

The program is written in Java using the JDK1.3 (Java Development Kit) from Sun Microsystems (Sun Microsystems, 2000). The program was designed and tested under Microsoft Windows 98.

\section{Software and hardware environment}

For executing JECP/ED, a Java virtual machine, i.e., J2RE, must be installed on the computer. No special hardware is required.

\section{Documentation}

Documentation is provided in the form of HTML documents. An on-line version of this documentation is available at http://www.unl.edu/CMRAcfem/XZLI/programs.htm .

\section{Availability}

The program in compressed form (jecp.zip) including a set of crystal structure files is available at http://www.unl.edu/ CMRAcfem/programs.htm . A registration code can be obtained by e-mail - xli2@unl.edu - from the author. Without a registration code this program works in demo mode.

\section{References}

Berg, B. S., Hansen, V., Midgley, P. A. \& Gjonnes, J. (1998). Ultramicroscopy, 74, 147-157.

Gjonnes, J., Hansen, V., Berg, B. S., Runde, P., Cheng, Y. F., Gjonnes, K., Dorset, D. L. \& Gilmore, C. J. (1998). Acta Cryst. A54, 306-319.

Sun Microsystems (2000). http:// www.sun.com

Vincent, R. \& Midgley, P. A. (1994). Ultramicroscopy, 53, 271-282. 